\title{
Decolonization, Foreign Aid and Post-Independence Nigerian Underdevelopment
}

\author{
James Olusegun Adeyeri, Adeniji, A. Stephen
}

To Link this Article: http://dx.doi.org/10.6007/IJARBSS/v11-i4/9736

DOI:10.6007/IJARBSS/v11-i4/9736

Received: 07 February 2021, Revised: 10 March 2021, Accepted: 27 March 2021

Published Online: 24 April 2021

In-Text Citation: (Adeyeri \& Adeniji, 2021)

To Cite this Article: Adeyeri, J. O., \& Adeniji, A. S. (2021). Decolonization, Foreign Aid and Post-Independence Nigerian Underdevelopment. International Journal of Academic Research in Business and Social Sciences, 11(4), 884-891.

\section{Copyright: (c) 2021 The Author(s)}

Published by Human Resource Management Academic Research Society (www.hrmars.com)

This article is published under the Creative Commons Attribution (CC BY 4.0) license. Anyone may reproduce, distribute, translate and create derivative works of this article (for both commercial and non-commercial purposes), subject to full attribution to the original publication and authors. The full terms of this license may be seen at: http://creativecommons.org/licences/by/4.0/legalcode

\section{Vol. 11, No. 4, 2021, Pg. 884 - 891}

Full Terms \& Conditions of access and use can be found at http://hrmars.com/index.php/pages/detail/publication-ethics 


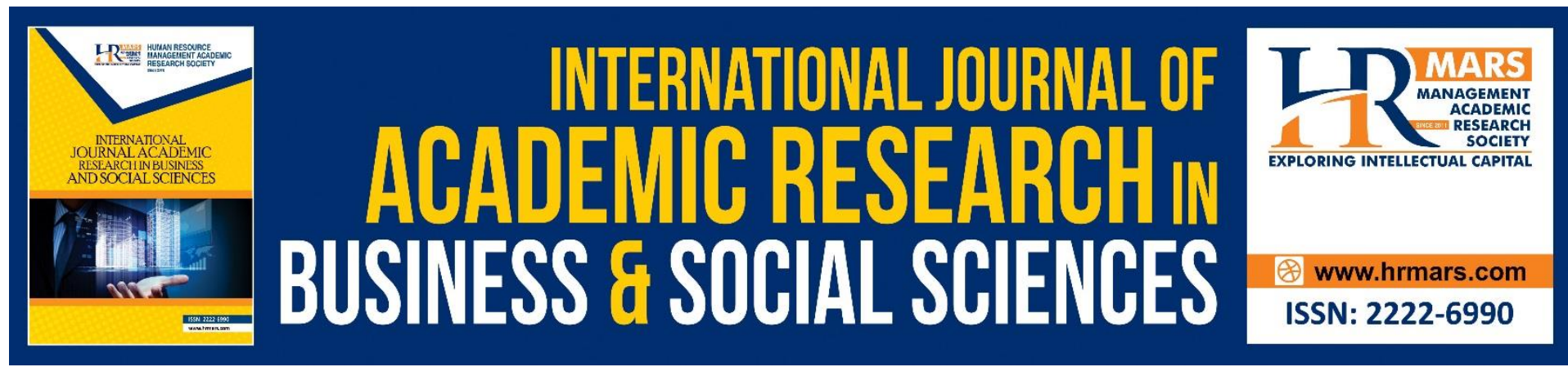

\title{
Decolonization, Foreign Aid and Post- Independence Nigerian Underdevelopment
}

\author{
James Olusegun Adeyeri, PhD, Adeniji, A. Stephen
}

Department of History and International Studies Lagos State University, Ojo, Nigeria

Email: jadeyeriolusegun@gmail.com, olusegun.adeyeri@lasu.edu.ng

\begin{abstract}
Aside meeting Nigerian nationalist needs more than before, the decolonization period was also characterized by the intensification of the economic exploitative use of Nigeria as a colony, particularly during the Second World War. The government pursued the maximum utilization of Nigeria's economic resources through highly rigid policies such as forced labour and drastic lowering of producer prices in order to boost production of Nigerian product such as rubber, palm oil, tin and groundnuts, which were strategic to Britain's war effort. The government disrupted the internal marketing systems and introduced state controlled marketing of Nigeria agricultural exports. The colonial educational system was structured to produce clerks but not economically productive skilled personnel who can create wealth. This paper contend that just as colonial Nigerian society was unequal (privileged British colonists and poor Nigeria subjects), Nigeria currently suffers from inequality within the contemporary globalized international economic system mainly due to the British-imposed colonial economic model of primary products exports as the cornerstone of Nigeria's national economy during the decades preceding independence. Instead of initiating policies that would jump-start Nigerian industrialization, the British colonial policy of dependence on primary products laid the foundation for post-independence Nigeria's underdevelopment. Nigeria's current crisis of development is further aggravated by decades of ineffective foreign development aid mainly because such aids are largely not negotiated but dictated, and managed by officials of the international or multilateral aid agencies who do not have adequate understanding of Nigerian development needs and circumstances. Such aids, in most cases, thus result in a worsening economy characterized by increasing unemployment, spiral inflation, hitches in the productive mechanism, and widening income inequality. This paper explores the role of British decolonization process, and foreign aid in postindependence Nigerian underdevelopment. The study concludes that home-grown approaches anchored upon good governance, effective utilization of resources, probity and accountability are crucial to Nigeria's recovering from its current condition of underdevelopment. It adopts the historical analytical method.
\end{abstract}

Keywords: Decolonization, Economic Exploitation, Foreign Aid, Nigeria, Underdevelopment. 


\section{Introduction}

Nigeria, like most other African and Third World Countries, had since independence continued to grapple with a deepening crisis of underdevelopment in an increasingly globalizing world. This crisis of underdevelopment is epitomized by lack of industrialization, dwindling economic productivity, ailing imports based economy, weakening currency and hyper inflation, mounting unemployment rate and acute mass poverty, among others. This paper is a historical reconstruction of the impact of British decolonization process, and foreign aid on Nigeria's development in the post-independence era. By the same token, it seeks to provide some explanations for Nigeria's current status of inequality within the contemporary global economic system.

\section{Decolonization Years and the Foundations of Nigeria's Underdevelopment}

Decolonization was one of the major developments in Nigeria during the Second World War years. In a sense, colonialism peaked during the war years, particularly in terms of mobilization and exploitation of productive and manpower resources for the interest of the British metropole. Decolonization took place alongside the beginning of the economic policies of "colonial development and welfare" within an expanding colonial and evolving neo-colonial, economic framework (Harneit-Sievers, 1990:31). Although, Nigeria engaged in direct military involvement in World War II by partaking in shipping and aircraft supply, transportation and infrastructure, as well as service in the British armed forces, her major role in the war was economic.

In this regard, Nigeria served as a source and supplier of raw materials, especially export items, such as palm oil, palm kernels, groundnuts, cocoa, cotton, rubber, peanuts, coal and tin (New World Encyclopedia, 2015). There is need to state that Nigeria's colonial economy depended on cocoa, palm produce, and groundnuts, the country's three major export crops at the time. For purposes of the war, the British colonial government established control over the three major export crops primarily to optimize production and supply. Wartime agricultural production in Nigeria was undoubtedly high despite the existing low prices. Various methods were adopted for labour mobilization and control towards the objective of maximum production output. There is evidence to show that in the case of tin mining, Nigeria's only major, but militarily most important, mineral export, the strategy was crude. As an illustration, from 1942 to 1944, over 90,000 labourers were conscripted for mining in the Jos area. Each worked for a period of three to four months, under living conditions that created high mortality rates, and paid only minimum wage, part of which was even in kind. Conversely, in respect of agricultural production, the colonial government relied on incentives and persuasion, instead of force or pressure. This was mainly because production relied upon the single small farmers scattered all over the country. Thus, the labour mobilization measures adopted included propaganda through newspapers, films and radio. Others include pressure on traditional rulers, local production competitions, and the use of school children for palm kernels and rubber collection (Souter, 1984; Harneit-Sievers, 1990:34, 37).

In respect of export marketing of Nigerian produce, the colonial administration introduced tight control. This sphere was mainly under the control of European companies under their umbrella body, Association of West African Merchants (AWAM) working as buyers for the West African Produce Control Board (WAPCB), earlier created in 1942 to centralize and enhance the organisation of purchasing and shipping, and achieve the most efficient 
utilization of available resources. Under this setting, the internal produce markets were divided among the European companies, each having its purchasing quota, which was determined by its performance in the late years preceding the control regime. Due to this policy, competition among the companies were greatly undermined, and prospective new operators were shut out of the produce markets. More significantly, the tight restrictions also precluded small trading companies (Nigeria, African and Lebanese) domiciled in Nigeria, which were about to commence direct export of produce. It must be added that the WAPCB licensing control also required the approved companies to direct their exports to specific destinations, perhaps to prevent supply to enemy territories. European control of the produce export business remained tight till the late 1940s (Muojama, n.d:53-54; Harneit Sievers, 1990:36, 39; Bauer, 1954:204; Williams, 1953). On the whole, Britain's wartime decolonization policies in the economic sphere denied Nigeria an 'early' take-off of genuine national industrialization and economic development, but instead laid the foundation for future crisis of underdevelopment and socio-economic inequality within the international system.

During the post-war years, Britain's decolonization policies (especially the political ones) were also unfavourable to Nigeria's future development and ability for veritable participation in post-independence global economic and political system. From 1945, the British administration in Nigeria discerned the need for containment of nationalism. This gave birth to the subsequent set of policies under the aegis of constitution-making (from the early 1950s), which sought to control the force of Nigerian nationalism and control the pace of devolution of power. This was meant, partly, to sustain Britain's position as a world power, especially in the economic and strategic spheres, against the evolving upsurge of Nigerian nationalism. Through this policy, Britain tried to forstall Nigerian nationalist demands which may threaten Britain's vital interests and thus, maintain specific British interests on which her existence as a trading country depended. To achieve this objective, British colonial officials decided on the need to create a class of Nigerian nationalist leaders with a vested interest in cooperation with the colonial government. The attitude of the colonial government cooperating with the moderate Nigerian elements and encouraging them to take over colonial leadership after 1945 should indeed be understood within this context. It is worth noting that from 1950, the colonial government effectively precluded radicals from Nigerian nationalism by proscribing the Zikist Movement, imprisoning labour leaders such as Nduka Eze, and discouraging Nigerian youths from associating with radical youth organisations outside Nigeria (Olusanya, 1973:121; Lawal, 2010:41-42). As Lawal aptly summarized the situation:

Undoubtedly, these were years in which the colonies were not been prepared for outright independence, but for the kind of political experiment demanded by the climate of the period. The sustenance of this moderate class of nationalists throughout the era of transfer of power was one of the goals of constitution-making which was largely to keep Britain in firm control of the events of those crucial years and indeed, to provide the major weapons of administering the emergent nation (Lawal, 2010:41-42).

Significantly, these decolonization policies that were based on British selfish interests, favouritism and partiality effectively shut out the radical nationalists and the possibilities of a 
well-grounded post-independence national development agenda and role in the comity of nations.

British colonial educational policy also undermined the prospects of genuine development in the post-independence era. Due to the realization of the necessity of training the people for support services to the colonial administration, the government emphasized the teaching of English Language in all classes at the expense of native (Nigerian) languages and dialects. In the upper classes, such as Standard Five and Six, the History syllabus was dominated largely by European topics, while the syllabi of other subjects (perhaps with the exception of Geography),were, to a great extent, British in outlook (Coleman, 1986; Fsqaham, 1966; Orr, 1965). This type of education, by its design and manifestation, produced clerks and bookkeepers instead of economically productive workers who posses the requisite skills for economic production and wealth creation (Words Press, 2009). Unfortunately, this negative trend was sustained by the Nigerian political class that took over power from the British colonialists at independence in 1960.

\section{Foreign Aid, Neo-Colonialism and the Crisis of Underdevelopment in Post-Independence Nigeria}

The 1940 Colonial Development and Welfare Act, like that of 1929, was to some extent, paternalistic in nature. The policy ostensibly sought to protect the interests of the British colonies by "developing" their natural resources for an improved standard of living. In order to solve the problem of underdevelopment in Nigeria and other British colonies, the colonial administration decided to provide them with increased external assistance. Under the 1940 Act, the government would implement an annual expenditure of five million British pounds on capital, agriculture, education, health and housing for 10 years, and 500,000 pounds on research over a 10-year period. In addition, a Colonial Research Advisory Committee was created. The implementation of the entire expenditure plan was rested in a Colonial Development and Welfare Advisory Committee, which consisted of official and non-official members. It is significant to note that the 1940 Act ultimately placed premium on agriculture, but failed to effect changes in other key sectors such as communications, infrastructure, health and cooperative societies. It would appear that the Act was a political ploy to deploy minimum economic reforms to placate nationalist agitators and stem the worsening crisis of colonial rule (Adeniji, 1998:138,143; Hancock, 1942:324).

The 1945 Colonial Development Welfare Act, like previous ones, was informed by the underlying imperialist philosophy that Britain must continue to profit from her colonies in order to recover from the economic backlashes of World War II. The motive was to help the colonies in a way that the metropole would also benefit from them. This was particularly necessary given Britain's post-war indebtedness to the United States of America (USA) and the US dollar being the only strong currency. As the USA was in need of tropical products like minerals, cocoa, coffee, etc, Britain sought to obtain these from her colonies and sell for scarce dollars. Thus, in the post-war circumstances, Britain deemed it necessary to invest in the colonies in order to obtain raw materials, and to maintain political control at least until sufficient profits were realized. In this connection, the social welfare programme was intended to produce a healthier population that would ensure increased production for export. Nonetheless, while British Colonial Development and Welfare grants and similar grants from Britain were the only form of official foreign aid to Nigeria during the first half of 
the $20^{\text {th }}$ century, some little sums started trickling into the country from the United States government as from 1954. It is important to state that this U.S. assistance was not motivated by altruistic considerations for Nigeria, but largely by the crucial need to contain the spread of communism in Africa. American aid till the end of the colonial period applied mainly to road development, equipment procurement, development of the Enugu Coal Mines, and agricultural services and development etc. In subsequent decades, the U.S. provided loan aids generally to finance long-term capital programmes that were crucial to economic infrastructure such as roads, power plants, telecommunications and higher education facilities, etc. upon which future development depended. However, American aid commitments did not immediately translate into disbursement of funds, as Nigerian government officials could not utilize most of the aid money due to various technical problems (Adeniji, 1998:152, 200, 250, 251; Ate, 1987:76).

Post-colonial Nigeria inherited from the colonial state the culture of dependence on foreign aid and capital. Unfortunately, the process, conditions and implementation of foreign aid and grants in Nigeria are inimical to meaningful socio-economic development of the country. It is a popular notion in Nigeria that the foreign aid agencies such as the World Bank and International Monetary Fund (IMF) do not negotiate with the government, instead they dictate the terms and conditions of Official Development Assistance (ODA) programmes. Even the implementation of such aid programmes is usually not under the Nigerian government's control, but tele-guided by the aid agencies through their foreign officials who may not adequately understand the Nigerian peoples circumstances and needs. As Gena aptly noted, the Agricultural Development Project Scheme (ADPS) is "World Bank directed and not World bank Assisted" because the World Bank Project Evaluation regime underscores the fact that the World Bank is in control of who gets what, how and when (Aluko \& Arowolo, 2010: 121122; Articles NG, 2013). As an illustration, in 1980, following a disagreement over implementation of the statewide Agricultural Development Project(ADP) in Kaduna State, the state government declared in protest that it would jettison the project, rather than surrender to the World Bank (New Nigerian, 20 November 1980). Similarly, a particular community in Ilorin, Kwara State resorted to public protest over its dissatisfaction with the manner of implementation of one of the ADPS, particularly as regards the siting of the project's headquarter (Articles NG, 2013). The nature, conditionalities and implementation of foreign aid projects in post-independence Nigeria are products of neo-colonialism, and reflective of growing dependency of Nigeria within the international system, a process initiated by Britain during the colonial and decolonization years.

There is need to emphasize that the foundation of Nigeria's current underdevelopment was laid by British imperialism which left the Nigerian economy distorted and disarticulated such that autonomous economic and technological development became problematic. The dependent colonial economy created by Britain, aggravated by neo-colonial foreign aid programmes, inevitably resulted in Nigeria being structurally disadvantaged in international division of labour, and continually subjected to financial, trade, technological, military and psychological dependence (Articles NG, 2013). There is a two-way relationship between Nigeria's current underdevelopment and her historical dependency status within the global system. 


\section{Conclusion}

We have shown in this discourse that the educational, ideological, and structural foundations of the Nigerian state during British colonial rule was inimical to genuine national development after the attainment of independence on 1 October 1960. The study also revealed that the Nigerian political elite that took over governance at independence did not, and have not remedied the fundamental anomaly in the Nigerian state they inherited from the colonial administrators. Nigeria's post-independence crises of underdevelopment, characterized by acute food crisis, unemployment, poverty, poor socio-economic infrastructure, criminality and insecurity, are logical outcomes of the largely unsuitable and inimical British decolonization process, Western foreign aid, and other neo-colonialist tendencies. Over 66 years after political independence, Nigeria remains primarily an exporter of raw materials and importer of foreign manufactured goods, like in the colonial era, with the attendant negative socio-economic consequences. The deepening crisis of underdevelopment has continued to subject Nigeria and Nigerians to the vagaries of contemporary global inequality. Nigeria's underdevelopment in the post-colonial era, is further aggravated by abysmal corruption in official and private sectors, and high and low stratas of society. For the anti-corruption fight proclaimed by the Muhammadu Buhari-led government to yield meaningful and enduring results, it must be holistic and not partial or sectional. Finally, to stem the tide of worsening underdevelopment and negative effects of global inequality, it is crucial for the Nigerian political class and entire citizenry to immediately shed the cloak of colonial and neo-colonial mentality and embrace home-grown approaches predicated upon good governance, effective utilization of resources, probity and accountability, instead of continued over-reliance on foreign aid and models of development.

\section{References}

Adeniji, A. O. (1998). "Official Development Assistance to Nigeria 1900-1993: A SocioEconomic and Political Analysis", An Unpublished Ph.d Thesis, University of Lagos, Lagos, Nigeria

Aluko, F., and Arowolo, D. (2010). "Foreign Aid, The Third World Debt Crisis and the Implication for Economic development: The Nigerian Experience", African Journal of Political Science and International Relations, vol. 4, no. 4

Articles, N. G. (2013). "Impact of Foreign Aid on Nigeria's Socio-Economic Development", Available at www.articlesng.com(Accessed 24-10-2016)

Ate, B. (1987). Decolonization and Dependence: The Development of Nigeria-U.S. Relations 1960-1984 (London: West view Press)

Bauer, P. T. (1945). "Statistics of Statutory Marketing in West Africa 1939-51", Journal of the Royal Statistical Society, vol.117, no 1

Coleman, J. S. (1986). Nigeria: Background to Nationalism (Benin: Broburg and Wistrom)

Fsqaham (1966). Government and Mission Education in Northern Nigeria (Ibadan: I.U.P)

Hancock, W. K. (1942). Survey of British Commonwealth_(London: O.U.P)

Harneit - Sievers, A. (1990). "The Second World War and Nigeria's Political Economy" in T. Falola. Modern Nigeria: A Tribute to G. O. Olusanya (Lagos: Modelor)

Lawal, O. (2010). "From Colonial Reforms to Decolonization: Britain and the Transfer of Power in Nigeria, 1947-1960", Journal of the Historical Society of Nigeria, vol. 19

Muojama, O. G. (n.d.). "Cocoa Export Permit and Quota System in Nigeria during World War II, 1939-45", UJAH:Unizik Journal of Arts and Humanities.

New World Encyclopedia (2015). "Nigeria”, Available at 
Www.Newworldencyclopedia.Org(Accessed15-10-2016

Olusanya, G. O. (1973). The Second World War and Politics in Nigeria 1939-1953 (London Ibadan: Evans)

Orr, C. W. (1965). The Making of Northern Nigeria (London: Frank Cass)

Souter, D. (1984). "Labour Policy in Nigeria during the Second World War and Conscription for the Nigerian Tin-Mining Industry", Conference Paper, School of Oriental and African Studies, London, May

Williams, D. M. (1953). "West African Marketing Boards”,_African Affairs, vol. 52, No. 206

Words Press. (2009). "The Colonial Economy: The Indigenization of Colonialism and Underdevelopment", Available at: https://henryik2009.wordpress.com the ... (Accessed 22-10-2016) 